\title{
Editorial
}

Volume 8 Number 2 December 2009

\section{Biomedicine and Islamic Jurisprudence in Malaysia - Quo Vadis ?}

Islam is a way of life that rhymes with human nature. ${ }^{1}$ In harmony with its strengths, acknowledging its weaknesses and offering guidance to those who submit. ${ }^{2,3}$ Despite many misconceptions on compulsion ascribed to Islam, its practice is purely by choice. ${ }^{4,5}$ Belief in Islam is a conviction to a resolute and eternal truth, which is the unity of God. Living it, is harmonising the daily physical needs to that of constant spiritual enlightenment, neither in mutual exclusion but rather, complementary and symbiotic.

On the other hand, the practice of Islam is varied, a plethora of different schools of Islamic jurisprudence and a myriad of races, cultures and languages. ${ }^{6}$ It has to be distinguished between specific acts of worship such as the solat (daily prayers), saum (fasting) and hajj (pilgrimage) which have been etched in stone, unchanging and purified for eternity, to that of general acts of faith and worship which are necessarily varied through the vestiges of geographical, cultural and temporal separation. ${ }^{7}$

Herein lies the challenge for contemporary scholars, commentators and physicians alike. To what extent is divergence, be it geographical, cultural or temporal, tolerated or even encouraged and in what areas ? Can divergent practices connote a unity of faith and belief or is it mutually exclusive ? These are the sentiments that underpin any discussion on Islamic jurisprudence vis-à-vis contemporary biomedicine and medical ethics.

Medicine has always had a harmonious relationship with Islam, Muslim scholars and physicians alike. Early Muslim physicians were experts not only in medicine but also acknowledged jurists in their own right. Examples included Ibn Sina (Avicenna) and Ar Razi (Rhazes). Their view of medicine is summed up well by al Iz ad Din ibn Abdul Salam who opined, "the aim of medicine is to preserve health, restore it when it is lost, remove ailments or reduce its effects. To reach that goal it may be essential to accept the lesser harm in order to ward of the greater one; or loose a certain benefit to procure a greater one". ${ }^{8}$

The principles of Islamic jurisprudence revolves around the preservation of five cardinal elements of human life as laid out by al-Syatibi in his Maqasid al Syari'ah (reasons for juridical code); Deen (religion, faith or creed), Nafs (Life), Aql (Mind), Maal (Property) and Nasl (Lineage). ${ }^{9}$ These elements are in turn governed by the determination of the Qawaid al Maqasid (derivation for the reasons) which include principles of intent, degree of certainty, level of injury, underpinning hardship and customary observances or norms. ${ }^{10}$

An example of how juridical injunction can change based on the underlying set of circumstances follows. Porcine consumption is disallowed in Islam. Not only pork but the use of any part of the meat, organs, its derivatives or even the bio-molecular breakdown particles such as those utilised in the pharmaceutical and cosmetic industries.

Life however, and its preservation, is sacrosanct in Islam. ${ }^{11}$ Achieving this end may entail the suspension of juridical injunctions and allowance of what is forbidden (rukhsah). Examples include the use of porcine-derived medicaments for the treatment of heart attacks when no suitable option is available and the physical act of pork consumption to stave off hunger and imminent death when no other food is obtainable. ${ }^{12}$ Insofar as no viable alternative (bovine etc) is accessible, the suspension of the juridical injunction against pork consumption remains.

The predominant consideration in this instance is firstly the preservation of life as is 
imbued in al Syatibi's Maqasid al Syari'ah. Secondly, the purpose of the religion is as an example to mankind, a mercy unto the world afforded by its flexibility in the face of adversity. ${ }^{13}$ The religion is a guide, a beacon that serves to illuminate ones life towards God-conciousness, attuned to ones weaknesses and strengths, firm in the preservation of the unity of belief but flexible in the enforcement of juridical injunctions in light of mitigating circumstances.

This dynamic nature of the religion (i.e. syari'ah) is a reflection of the nature of creation in all its diversity, its continuous social and psychological evolution and its geographical and temporal distinction. Differences should be critiqued, embraced and encouraged as a mercy and blessing insofar as the underpinning conceptual unity of faith is preserved. It should also be free from any biases such as taqlid (blind following without thought) or asabiyyah (geographical, cultural or linguistic preference merely on that basis) or influenced by the vigour of a select few (bourgeois or governmental influence).

Scientific advances should always be evaluated within this paradigm. Will the procedure / medication afford a communal advantage rather than individually ? Will it help to preserve life and parry illness or will it prolong hardship ? Will it encourage reflection and God-conciousness or will it engender emancipative pride? In short every advance should be evaluated by the sum of all its parts rather than preferential assessment of one aspect of the whole. Only with this worldview will the Muslim ummah (nation) hope to forge ahead as is promised by God in the verse;

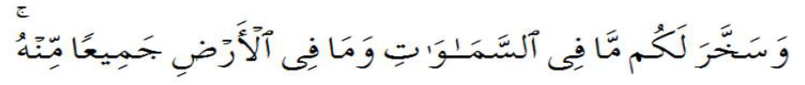

And it has been made available to you all that is in the heavens and all that is in the earth; it is all as a favour and kindness from Him

(Al Jaathiyah 45:13)

\section{Dr Azarisman Shah Mohd Shah}

Deputy Dean (Academic)

International Islamic University Malaysia

\section{REFERENCES}

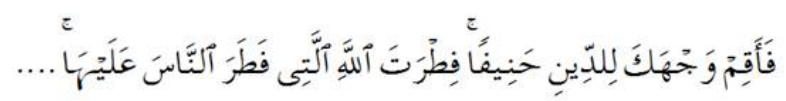

1. So set thy purpose ( $O$ Muhammad) for religion as a man by nature upright - the nature (framed) of Allah, in which He hath created man. (Ar Rum 30:30)

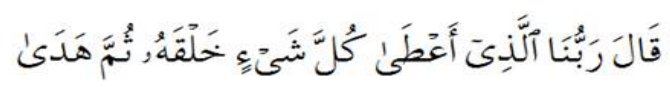

2. He said: "Our Lord is He Who gave to each (created) thing its form and nature, and further gave (it) guidance." (Ta Ha 20:50)

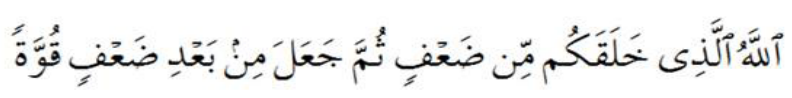

3. Allâh is He Who created you in (a state of) weakness, then gave you strength after weakness, (Ar Rum 30:54)

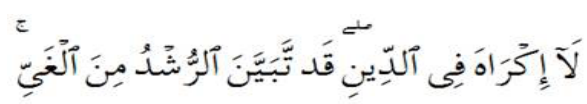

4. Let there be no compulsion in religion. Truth stands out clear from Error,.. (Al Baqarah 2:256)

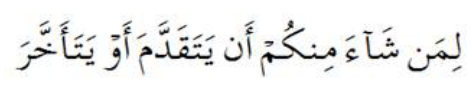

5. To any of you that chooses to go forward (by working righteous deeds), or to remain behind (by commiting sins) (Al Muddathir 74:37)

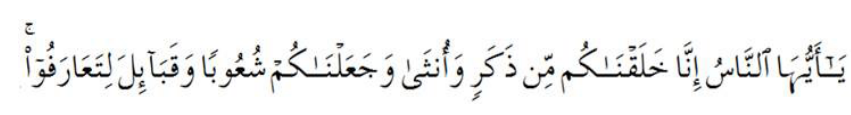

6. O mankind! We have created you from a male and a female, and made you into nations and tribes, that you may know one another. (Al Hujurat 49:13)

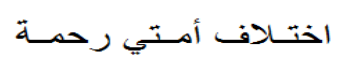

7. 'Ikhtilafi ummati rahmah - Differences in opinion is a blessing on mankind', a saying commonly ascribed to Qasim ibn Muhammad an 'alim from Madinah and Caliph 'Umar ibn Abdul Aziz.

8. Albar MA. Seeking remedy, abstaining from therapy and resuscitation: an Islamic perspective. Saudi J Kidney Dis Transplant 2007; 18:629-37

9. Syatibi. Al-Muwafiqaat fi Usul al-Shariah. Dar alMakrifah, Beirut.

10. Al-Kailani. Qawaid al-Maqasid Inda al-Imam asSyatibi. Dar al-Fikr, Damsyik.

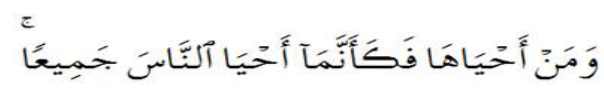

11. .... and if anyone saved a life, it would be as if he saved the life of all mankind, (Al Ma'idah 5:32) 


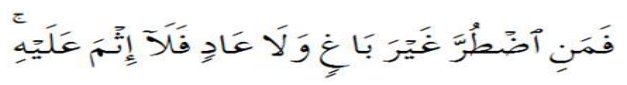

12. But if one is forced by necessity without wilful disobedience nor transgressing due limits, then there is no sin on him. (Al Baqarah 2:173)

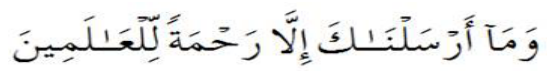

13. And We have sent you (O Muhammad SAW) not but as a mercy for the "Alamîn (mankind, jinn and all that exists). Al Anbiya’ 21:107 
THE INTERNATIONAL MEDICAL JOURNAL

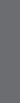

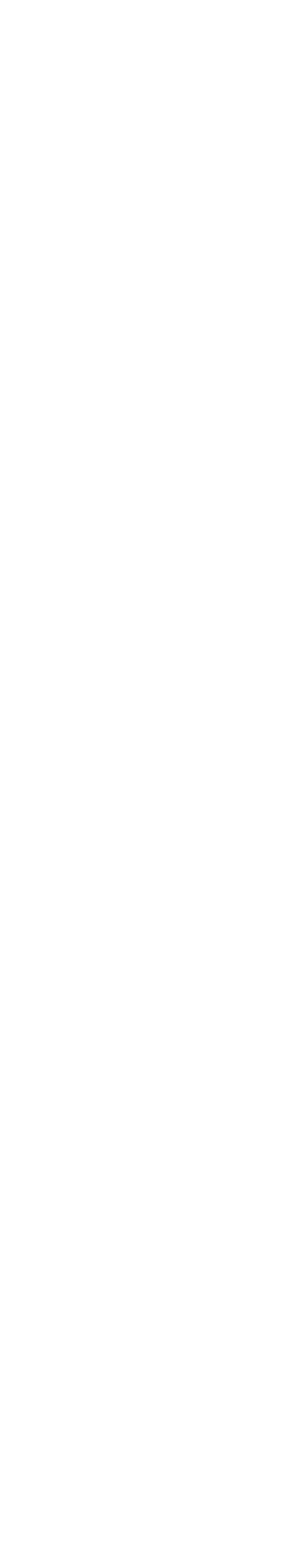

